\title{
Wojciech Swędzioł
}

\author{
Akademia Wychowania Fizycznego w Krakowie
}

\section{PRAGMATYKA KOMUNIKACJI WERBALNEJ W PRZESTRZENI WSPINACZKOWEJ. WYBRANE PRZYKŁADY Z ZAKRESU TYFLOPEDAGOGIKI PRZEŻYĆ}

\begin{abstract}
Pragmatics of verbal communication in the sport climbing. Selected examples from the range of experience typhloeducation

Increased in recreational climbing interest which is used by educators and therapists due to the specificity of the discipline equipped with a number of specific advantages. In order to optimize the teaching, to ensure safety and for building lasting motivation, it is necessary to efficient communication. The article presents the results of research on the quality of communication in teaching young climbing people with damaged eyesight. The presented conclusions based on participatory action research using the method of service learning enabled to select the universal means of communication and recommendations relating to the selected examples in the field of experiential learning.
\end{abstract}

Key words: typhlopedagogy, experience pedagogy, communication, climbing

„Najtrafniejsze jest to słowo, które każdy natychmiast zrozumie".

Georg Christoph Lichtenberg ${ }^{1}$

\section{Wprowadzenie}

Wspinaczka halowa i skałkowa oraz łącząca się z nimi turystyka wspinaczkowa są dyscyplinami bardzo atrakcyjnymi nie tylko ze względu na obecność psychofizycznego wyzwania (subiektywnie postrzeganego ryzyka), ale również stanowią atrakcję w porównaniu z tradycyjnymi dyscyplinami z kanonu wychowania fizycznego. Dowodzą tego liczne prace naukowe i wdrożeniowe poświęcone wykorzystaniu wspinaczki jako narzędzia terapii (Hofferer, Royer 2001; Krick 2001; Esser, Bartik 2002; Lillotte

${ }^{1}$ Georg Christoph Lichtenberg (ur. 1 lipca 1742 r. w Ober-Ramstad, zm. 24 lutego 1799 r. w Getyndze), niemiecki przedstawiciel Oświecenia. Od 1770 roku profesor matematyki i nauk przyrodniczych na uniwersytecie w Getyndze. Twórca i jeden z najwybitniejszych przedstawicieli niemieckiej aforystyki. 
2003; Caprano, Sinz 2008; Geisteiner 2009; Haag 2009; Schnitzler 2009). Aktywność wspinaczkowa jest zarówno zabawą wykorzystującą atrakcyjne przybory i przyrządy (sprzęt wspinaczkowy, ściana wspinaczkowa), jak i działaniem odwołującym się w symboliczny niemal sposób do transgresyjnej koncepcji człowieka. Obfituje ona w liczne swoiste walory, możliwe do wykorzystania w pracy z dziećmi i młodzieżą o specjalnych potrzebach, między innymi również w tyflopedagogice (Swędzioł 2013a: 63-68). W celu optymalizacji procesu nauczania oraz zapewnienia uczestnikom zajęć bezpieczeństwa konieczna jest sprawna komunikacja. Sprawna, ponieważ czas, który ma do dyspozycji początkujący wspinacz, jest ograniczony siłą i wytrzymałością jego mięśni przedramienia, komunikacja musi być zatem nie tylko zrozumiała, ale dostarczająca odpowiednich informacji w sposób dostatecznie szybki, precyzyjny i pozytywnie motywujący. Te cechy dobrze oddaje określenie komunikacji jako zwinnej.

\section{Funkcje języka. Wybrane aspekty}

Językowi przypisywane są trzy podstawowe funkcje: kognitywna, społeczna i afektywna. Funkcja kognitywna (poznawcza) polega na wyrażaniu myśli, sądów, idei, pojęć oraz na ich realizowaniu. Wiąże się ona ściśle z procesami poznawania świata przez człowieka. Każdemu znakowi, wyrazowi języka nie tylko przyporządkowane jest znaczenie leksykalne, ale także określa on kategorie kognitywne, które są bogatsze i szersze niż znaczenie leksykalne. Każde wyrażenie językowe może być interpretowane w świetle jakiejś określonej kategorii kognitywnej. Funkcja społeczna odzwierciedla rolę języka w relacjach społecznych. Język staje się w tym znaczeniu narzędziem tworzenia i regulowania relacji społecznych. Jest też najważniejszym narzędziem podziału kompetencji i układu ról społecznych w różnych sytuacjach (np. relacje nauczyciel-uczeń). Funkcja zaś afektywna (emotywna, ekspresywna) jest związana z przekazywaniem emocji. Każda z tych funkcji odnajduje swoje miejsce w warsztacie pracy nauczyciela, dla którego pomimo rozległości i ciągłego rozbudowywania się swego warsztatu (choćby o coraz bardziej zaawansowane technicznie audiowizualne środki informacji uzupełniającej) najbardziej podstawowym narzędziem pozostaje jednak słowo (por. Czabański 1998). Bogdan Czabański (1998) podkreśla, że w nauczaniu istotna jest sprawność kanału informacyjnego, a w kontaktach między ludźmi najwyższą wartość jako nośnik informacji ma słowo.

Sposób werbalnej komunikacji pomiędzy uczniem a nauczycielem może mieć zasadnicze znaczenie w tworzeniu klimatu sprzyjającego nauce ruchu. Przyjmując za Frankiem Rokoszem i Richardem Laptadem, że ruch fizyczny jest „artystycznym zabiegiem, wysiłkiem zakorzenionym w indywidualnej kreatywności pozostającym głęboko pod wpływem ciągle zmieniającego się kontekstu ruchu”, warto przywołać jego porównanie pracy nauczyciela do pracy ogrodnika „(..) który zapewnia ludziom możliwości lub okoliczności, w których będą mogli rozwijać się sami. Jest specjalistą, który dostarcza informacji zwrotnej, czy zmiany dokonują się we właściwym kierunku, czy też nie" (Rokosz, Laptad 1997). Podążając tym śladem, nie można nie podkreślić 
- wydawałoby się drugoplanowej, lecz arcyważnej - „dalekosiężnej” funkcji języka i jego wpływu na podtrzymanie motywacji. O ile bowiem język w swojej funkcji instruktażowej przyczynia się do opanowania umiejętności ruchowych, o tyle przejawem jego funkcji interakcyjnej będzie wszystko, co zachodzi pomiędzy nauczycielem i uczniem, a więc również wykształcenie, podtrzymanie i utrwalenie wewnętrznej motywacji do uprawiania określonej dyscypliny. Ryszard Winiarski twierdzi, że „tylko aktywne i dobrowolne uczestnictwo w lekcjach wychowania fizycznego pozytywnie angażuje emocjonalnie i dostarcza zadowolenia z samego udziału w zajęciach" (1992: 51). Od tego będzie zależała trwałość efektów nauczania wyrażona potrzebą uczestnictwa w kulturze fizycznej w wieku późniejszym. Jak sugeruje Winiarski (1992), jedną ze skuteczniejszych dróg, którą powinno podążać wychowanie fizyczne, jest droga polegająca na kształtowaniu motywacji wewnętrznej. Oczywiście motywowanie wykracza poza wykorzystanie tylko i wyłącznie nośnika informacji, jakim jest słowo. Jeżeli jednak nieumiejętne posługiwanie się językiem prowadzi permanentnie do porażek i frustracji, jakże odwoływać się do wykorzystania innych narzędzi nauczycielskiego warsztatu. Parafrazując łacińską sentencję Verba docent, exempla trahunt, można postulować: Przykłady pociągają, a słowa powinny je wspierać. W aspekcie edukacji fizycznej mającej przygotować jednostki do sportu całego życia, niezmiernie korzystne byłoby kształtowanie tak zwanej motywacji trwałej, umożliwiającej utrzymanie aktywności ruchowej przede wszystkim u dzieci średnio i mało sprawnych (Grabowski 1992).

W zakresie bliższych, bardziej instrumentalnych działań w pracy nauczyciela wspinaczki ${ }^{2}$ (ale również i nauczyciela wychowania fizycznego) język odgrywa przede wszystkim swą podstawową informacyjną rolę. U osób niewidzących ${ }^{3}$ drugi układ sygnałowy rozwija się szczególnie wybitnie, a to dzięki dynamizmowi kompensacyjnemu i przystosowawczemu (Sękowska 1981). Słowo kompensuje braki w poznaniu osoby niewidzącej, informując o niedostępnych dla bezpośredniego poznania zjawiskach, zmianach i procesach. Brak wzroku uniemożliwia również naśladownictwo i z tego powodu słowo staje się przewodnikiem w najróżniejszych sytuacjach codzienności. Otrzymanie informacji słownych umożliwia zastępstwo osobistych, bezpośrednich doznań, dotyczących właściwości i zjawisk świata, otaczającego osobę niewidomą.

\section{Specyfika instrukcji słownych kierowanych do osób niewidzących}

Zajęcia sportowe z osobami o uszkodzonym wzroku cechują się nadrzędną funkcją języka, który musi wypełnić swoje podstawowe informacyjne zadanie i przeciwstawia się modelowi, w którym można poradzić sobie bez języka, informując adresatów przede wszystkim za

\footnotetext{
${ }^{2}$ Celowo używam tu sformułowania nauczyciel wspinaczki (a nie instruktor). Jedną z powinności nauczyciela wspinaczki pozostaje bycie nośnikiem wartości, nie zaś wyłącznie instrukcji (Swędzioł 2013a).

${ }^{3}$ Jeżeli w tekście opracowania nie jest uzasadnione rozróżnienie stopnia uszkodzenia wzroku, używane będzie określenie „osoby niewidzące” jako odnoszące się zarówno do osób niewidomych, jak i słabowidzących, a zaczerpnięte z myśli znakomitego tyflopedagoga Włodzimierza Dolańskiego.
} 
pomocą wizualnej demonstracji (Friedrich 1989). Utrwaliło się też jednak założenie, że język sportu jest językiem ludzi widzących, przy czym zakłada się również, że do pełnego semantycznego zrozumienia leksykalnych pojęć konieczna jest wizualna kontrola sytuacji bądź demonstrowanego obszaru (Friedrich, Hildenbrandt 1990). Przykładem może być chociażby polecenie przyjmij pozycjęp płużna (pot.pług) będące określeniem stosowanym w nauce jazdy na nartach, odwołującym się do wizualnej percepcji i wykorzystania na zasadzie analogii, obrazu pługu śnieżnego. We wspinaczce przyjmujemy pozycję żabki, co w sposób analogiczny do poprzedniego przykładu nawiązuje do skojarzeń z obrazami zaczerpniętymi ze świata ludzi widzących. Podobnie i inne określenia są „wizualnie kodowane", gdzie w przypadku osoby widzącej rozumienie znaczenia konstrukcji czy pojęcia ułatwia zdolność do transferowania, czerpania z jego wizualnej wiedzy o świecie (Friedrich 1989). Niewidzący w zasadzie nie może polegać na takim źródle informacji. W zasadzie, należy się bowiem zastanowić, czy w przypadku użycia instrukcji zbliż dzioby nart do siebie konstrukcja i jej znaczenie staną się dla tej osoby dostatecznie czytelne. Widzący widzi te dzioby i wie, kiedy je zbliża, natomiast słowa pozycja i pług wymagają sięgania do wyobraźni, co dla osoby niewidzącej może okazać się ostatecznie prostsze (Czabański 1998). Warunkiem zwinnej, adekwatnej do potrzeb, komunikacji będzie zatem budowanie zasobów wyobraźni i wczesne rozkodowywanie pojęć. W nauczaniu wspinaczki przyzwyczajenie instruktorów do odwoływania się w swoich instrukcjach do informacji o widzialnym świecie jest naturalne i oczywiste, lecz w przypadku kontaktu z osobą niewidzącą wymagać będzie zmiany systemu kodowania lub wczesnego rozkodowania informacji. Przykładowo typowe wspinaczkowe instrukcje: sięgaj do tego okragłego, idź do ryski, teraz niebieski, złap go na robinhoodka - są dla osoby niewidzącej pozbawione informacji - oczywiście o ile przejście drogi wspinaczkowej, do którego odnoszą się te informacje, nie jest kolejną próbą i nie odbywa się w rozpoznanym terenie, gdzie taka informacja została już wcześniej rozkodowana. Co więcej, istotne wydaje się, że wczesne dekodowanie informacji i późniejsze posługiwanie się tym kodem (z punktu widzenia osoby niewidomej irracjonalnym, np. idź do ryski, co odnosi się do wizualnie rozpoznawanego punktu przestrzeni i kierunku działania) pogłębia poczucie pełnego uczestnictwa, rozumienia sensów i znaczeń wydawałoby się zarezerwowanych tylko dla osób widzących. Rozwinięcie takiego języka zespołu wymaga jednak czasu oraz występowania w tym czasie tak zwanego komentarza towarzyszącego, mającego na celu określenie punktów przestrzeni, kierunków działania oraz samych działań (Friedrich 1989). Analogicznie do proponowanego tutaj pojęcia języka zespołu, podkreślającego wspinaczkową więź bycia (na dobre i na złe) w zespole, Priesemann pisał o budowaniu „języka grupy uczniowskiej”. Przykładem takiego języka może być określanie kierunków działania, które w przypadku osób niewidzących są najczęściej formułowane w odniesieniu do tarczy zegara, a konkretnie do pozycji wskazówki godzinowej. Przykładowo polecenie idź na godzinę trzecią odpowiada informacji o zmianie kierunku o 90 stopni w prawo, przy czym pamiętajmy, że objętość komentarza/instrukcji jest odwrotnie proporcjonalna do jego czytelności. W warunkach fizycznego oddalenia od osoby komentującej, należy się spodziewać różnych zakłóceń (pogłos w hali, wiatr w czasie 
wspinaczki skałkach, inne wspinające się osoby). Aby zminimalizować wpływ zakłóceń na przejrzystość wysyłanych informacji, komentarz musi być jasny, niedwuznaczny oraz możliwie krótki. Są to zasady powszechnie obowiązujące w szeroko rozumianym sporcie wspinaczkowym. Wynikają one z jednej strony z zasad bezpieczeństwa, a co za tym idzie - z unikania komunikacyjnego chaosu, ponieważ jednoznaczność komunikatu może być warunkiem bezpieczeństwa (czego wymownym i „historycznym” w odniesieniu do tradycji wspinaczkowego szkolenia przykładem jest dwuznaczne, semantycznie biegunowo sprzeczne polecenie wybierz luz, składające się z dwóch przeczących sobie nawzajem poleceń wybierz i luz). $Z$ drugiej strony konieczność upraszczania języka jest związana z faktem, że czynnikiem limitującym czas wspinaczki jest zmęczenie mięśni przedramienia, a udzielenie szybkiej informacji (np. o lokalizacji kolejnego stopnia) może być warunkiem kontynuowania wspinaczki.

Z tego właśnie powodu słuszniejsze byłoby, zamiast idź na godzinę trzecia, użycie instrukcji idź na trzecią lub nawet trzecia. Abstrakcyjnym i humorystycznym przykładem laickiego przekazu mogłaby być forma wprowadzająca wspomniany komunikacyjny chaos: jak możesz to idź teraz tam, do tamtej ryski obok czerwonego oblaka... albo weź sobie blok i odpocznij, to ci dokładnie wyttumaczę.

Przykładem poprawnego kodowania instrukcji działań (w celu utworzenia kompaktowej, zwartej informacji) w początkowym etapie nauczania asekuracji można posłużyć się następującym kluczem. Uczeń ma wykonać kolejno czynności: wybranie liny z przyrządu asekuracyjnego - zablokowanie liny w przyrządzie - dołożenie ręki na linę blokującą - przełożenie dolnej ręki pod przyrząd na linie blokującej - przełożenie dolnej ręki z liny blokującej na linę asekurującą na wysokość twarzy. Używamy następujących poleceń: wybierz - blokuj - dołóż - przełóż - twarz. Ten komentarz umożliwia, sprawne i zrozumiałe informowanie o kolejnych, stosunkowo szybko po sobie następujących czynnościach. Ponadto polecenia takie - wypowiadane cyklicznie - zaczynają tworzyć dźwięczny rytm, w którym rytmiczność wypowiadanych słów przekłada się na rytmiczne, harmonijne działanie. W konsekwencji nawet braki na poziomie koordynacji ruchów nie są przeszkodą do szybkiego opanowania całej sekwencji, z czym będziemy mieć do czynienia, stosując rozbudowany, nieprecyzyjny i dysharmoniczny komentarz.

Kolejnym problemem w komentarzu towarzyszącym jest określanie dystansu. Formułowanie treści przekazu powinno odpowiadać potrzebom słuchacza. O ile w przypadku młodzieży określenia odnoszące się do jednostek metrycznych będą w pełni zrozumiałe, o tyle w przypadku dzieci lepiej będzie użyć odniesień do sfery najlepiej poznanej, czyli tej, której wyznacznikiem jest własne ciało. Zamiast sformułowania trzy metry przed tobą bardziej zrozumiałe będzie określenie cztery kroki przed tobą. W pionie, na ścianie wspinaczkowej, sytuacja nieco się komplikuje, ale i tu obowiązuje zasada, że zawsze odniesienia do kinestetycznego czucia przestrzeni, do czucia przestrzeni własnym ciałem będą bardziej zrozumiałe i precyzyjniejsze.

Jeżeli uczeń powinien postawić prawą stopę na kolejnym stopniu znajdującym się na wysokości lewego kolana, możemy użyć następującego kodu: prawa stopa (na) lewe kolano. Podobnie jeżeli kolejny chwyt dla prawej ręki znajduje się w prawo w skos, 
komunikujemy: prawa ręka na pierwsza, daleko - gdzie ostatni człon daleko jest jasną (choć wydawałoby się nieprecyzyjną) informacją o tym, że uczeń musi zrobić wszystko, by sięgnąć jak najdalej na godzinę trzynastą. W tym konkretnym przypadku konieczne jest oczywiście poprzedzenie tej instrukcji słownej (jeszcze na ziemi) informacjami o tym, jak ustawić ciało, aby zasięg ręki wykonującej przechwyt był jak największy.

Na podstawie dotychczas przedstawionych przykładów funkcję języka we wspinaczce z osobami niewidzącymi można postrzegać z jednej strony jako werbalną informację, czyli jako rodzaj werbalnej reprezentacji zadania poprzez instruowanie ucznia (instrukcja mająca stworzyć wyobrażenie o ruchu, który uczeń będzie próbował samodzielnie wykonać), z drugiej - jako interakcję, czyli proces zachodzący pomiędzy nauczycielem i uczniem, czego przykładem może być informowanie zwrotne. W obszarze instrukcji warto zwrócić uwagę na następujące problemy:

- wartościowanie i kolejność w hierarchii informacji;

- czas podania informacji;

- łączenie informacji dotykowych i werbalnych;

- rozgraniczenie informacji zależne od operacji (cel i wynik);

- kodowanie kinestetyczne i wyobrażeniowe;

- społeczna funkcjonalność komunikacji.

Wartościowanie i kolejność $\mathbf{w}$ hierarchii informacji. Jako pierwsze powinny zostać przekazane informacje opisujące miejsce/obszar przebywania oraz wytyczające zakres ruchu (również komunikacji), a dopiero później informacje określające działania osoby niewidzącej. W pierwszym przypadku będą to informacje o relewantnych punktach orientacji w przestrzeni (ze zwróceniem uwagi na akustyczne punkty orientacyjne; ulica, uczęszczany korytarz, dźwięk z głośników na hali sportowej lub na przykład strumyk, jeżeli zajęcia odbywają się w terenie naturalnym). Na tym etapie stosuje się aktywne rozpoznanie terenu, w czasie którego osoba niewidząca samodzielnie pozyskuje potrzebne informacje, przy czym konieczna jest asekuracja tych procesów połączona $z$ komentarzem towarzyszącym. Celem na tym etapie jest rozpoznanie obszaru przemieszczania oraz zapewnienie bezpieczeństwa działania. W praktyce określa się w czasie „spaceru” lokalizację obiektu w skali „makro” (np. położenie ściany wspinaczkowej w odniesieniu do pozostałych budynków, przystanku tramwajowego, lokalizację ściany w budynku i bezpieczne dojście pod ścianę, do szatni, do toalety itd.). W skali „mikro” należy określić lokalizację ściany w hali, zmierzyć krokami jej podstawę, wskazać na istotne punkty oraz zobrazować jej wysokość i kąt nachylenia. Wysokość ściany wspinaczkowej (którą można podać w metrach) najlepiej wizualizować ilością „paneli” składających się na jej całość. „Panel” jako element konstrukcyjny jest najczęściej czworobokiem, połączonym z pozostałymi (często identycznych rozmiarów) panelami wyczuwalnym spojeniem. Jeżeli pierwszy „panel” sięga od podstawy ściany wspinaczkowej do wysokości na przykład ramienia osoby stojącej przed nią, to informacja, że ściana ma wysokość 10 paneli będzie zdecydowanie bardziej relewantna niż informacja, że ściana ma wysokość $12 \mathrm{~m} \mathrm{i} 60 \mathrm{~cm}$. Kąt nachylenia (fachowo określany 
jako przewieszenie) ściany obrazuje czasami (w zależności od konstrukcji) kąt nachylenia jej bocznej krawędzi w zasięgu rąk osoby stojącej na ziemi. Informacją uzupełniającą będzie linia spadku liny wspinaczkowej zainstalowanej w układzie wędki (prostym, acz kompleksowym, ćwiczeniem pozwalającym na określenie rozmiaru nachylenia ściany, a równocześnie demonstrującym wytrzymałość liny oraz ideę tzw. wędki jest huśtanie się na linie). Kolejnymi informacjami w skali „mikro” będą detale budowy ściany, jej formacji, chwytów (kształt, wielkość). Chwyty warto jest poznawać nie tylko na ścianie. Warto poświęcić odpowiednio dużo czasu na ich poznanie, siedząc wygodnie i mając możliwość ich obracania, a co za tym idzie - poznanie wielu sposobów zarówno ich instalowania, jak i wykorzystania.

Kolejnymi informacjami będą te określające kierunek działania wspinacza. Z powodzeniem stosuje się na tym etapie opisywane wcześniej odniesienia do tarczy zegara oraz ciała osoby wspinającej się, które to techniki można również z powodzeniem łączyć (przykład: prawa stopa, lewe kolano, na dwunastą, co oznacza, że następny stopień dla prawej stopy znajduje się na wysokości lewego kolana, centralnie w osi pionowej ciała). Takie formułowanie instrukcji przyczynia się również do zwięzłości informacji, co w realiach wspinaczkowych jest kwestią zasadniczą, wiążącą się bezpośrednio z czasem podania informacji. Należy podkreślić, że od czasu podania informacji może zależeć sukces lub porażka. Szczególnie widoczne jest to właśnie w czasie wspinaczki, gdzie - jak już wspomniano - czynnikiem ograniczającym czas jej trwania jest zmęczenie mięśni przedramienia.

Czas podania informacji możemy różnicować w zależności od tego czy informacja jest podawana przed, w trakcie, lub po wyprowadzeniu ruchu przez ucznia. Dobrym przykładem będzie tutaj opisywana już wcześniej instrukcja stosowana w nauce asekuracji i obsłudze przyrządu asekuracyjnego. W początkowym etapie nauczania poszczególne składowe instrukcji Wybierz - blokuj - dołóź - przełóz - twarz podawane są przed zainicjowaniem ruchu, a w miarę upływu czasu i nabierania wprawy przez ucznia występują równocześnie z ruchem, regulując jego rytm. Moment, w którym uczeń wyprzedza instrukcję, świadczy o stopniowym opanowywaniu zadania.

Łączenie informacji dotykowych $\mathbf{i}$ werbalnych jest uzasadnione zgodnie $\mathrm{z}$ teorią schematów poznawczych, mówiącą o tym, na jakich aspektach rzeczywistości koncentruje się uwaga jednostki, jak interpretuje ona dostrzeżone informacje, a także - których z informacji użyje przy rozwiązywaniu problemów. Otóż schematy poznawcze dotyczące realnej rzeczywistości tworzą się i zmieniają bądź utrwalają, zwłaszcza poprzez rozpoznanie ruchowe, co dotyczy w szczególności osób niewidomych oraz ich poznawczych możliwości. Co za tym idzie, poznanie chwytów wspinaczkowych (kształt, sposoby 
wykorzystania), poparte werbalnym komentarzem będzie zdecydowanie bardziej efektywne niż samo tylko rozpoznanie dotykowe lub wyłącznie słowna informacja ${ }^{4}$.

Rozgraniczenie informacji zależne od operacji (cel i wynik). W tym przypadku poszczególne sekwencje rozwiązujące kompleksowe zadanie ruchowe są formułowane jako cel sam w sobie (aby osiągnąć oczekiwany wynik). Przykładowo - jeżeli oczekiwanym wynikiem jest wykonanie techniki skrętnej, udzielamy instrukcji wykonania relewantnych dla ucznia działań składowych, a nie instrukcji rozwiązania całej operacji (czyli skrętu). Dzięki temu można uniknąć (pod warunkiem że jest to wskazane!) dosyć typowego w sporcie formułowania zadań na stosunkowo wysokim poziomie skondensowania informacji. Oznacza to, że instrukcja zawierająca niejako receptę rozwiązania zadania składającego się z sekwencji ruchów zostaje zakodowana (w tym wypadku maksymalnie skondensowana). Przykładem może być wspinaczkowe polecenie skręć się. Wiadomo, że aby zrobić skręt, należy wykonać kilka następujących po sobie działań. Ta informacja umożliwiająca pokonanie trudnego miejsca (co rzeczywiście wiąże się z zastosowaniem techniki skrętnej) może zostać podzielona na relewantne dla ucznia składowe i przedstawiona następująco: prawa stopę wstaw na stopień na wysokości lewego kolana - teraz musisz się wyprostować i wstać na prawa noge - kolano i biodro zbliz do ściany - następny chwyt masz daleko nad głowa. To elementy składowe ruchu, gdzie wynikiem jest całość, czyli technika skrętna, a celami poszczególne działania. Czy tak przekazane instrukcje będą dostatecznie czytelne? Otóż ta sama informacja w opisywanym wcześniej języku zespołu mogłaby brzmieć następująco: prawa stopa na lewe kolano - dobrze! (informacja zwrotna o charakterze ogólnym) - teraz wyjdź na prawa i biodro do ściany - chwyt daleko na dwunastej. Różnica polega na zastosowaniu w języku zespołu skrótów informacyjnych, tak zwanych superznaków (Friedrich 1985), słów kluczy (Sas-Nowosielski 2002a, 2002b) powiązanych z poszczególnymi działaniami, lub na takim skróceniu informacji, aby przekazywanie treści odbywało się sprawnie, eliminując kolidujący ze skutecznością werbalizm.

Kodowanie kinestetyczne i wyobrażeniowe. Osoba niewidząca ze względu na brak wizualnego systemu odniesień, potrzebuje do rozwiązania zadania informacji dotykowych i akustycznych. Na bazie tego założenia powstaje pytanie, w jakim zakresie w czasie określania zadania należy uwzględniać ową specyficzną centralizację procesu postrzegania, opierając się na takich właśnie bodźcach. Przytoczone wcześniej przykłady poparte kilkuletnią praktyką wskazują, że wczesne dekodowanie informacji i późniejsze posługiwanie się tym kodem (z punktu widzenia osoby niewidomej często

${ }^{4}$ Najprostszym przykładem, doskonale egzemplifikującym teorię uzasadnionego łączenia informacji dotykowych i werbalnych w celu powstania i utrwalenia się właściwego schematu poznawczego, jest informowanie dziecka, że pokrzywa parzy - co na ogół nie przynosi zamierzonego rezultatu. Dopiero przypomnienie tej informacji, a właściwie jej połączenie ze stwierdzeniem tego faktu przez dotyk, utrwali w dziecku obiektywnie prawdziwy, poznawczy schemat o realnym świecie. 
irracjonalnym, np. złap niebieski - odnoszącym się do cech obiektów, punktów przestrzeni i kierunków działania) pogłębia poczucie pełnego uczestnictwa, rozumienia sensów i znaczeń wydawałoby się zarezerwowanych tylko dla osób widzących, a dodatkowo zacieśnia więzi w zespole wspinaczkowym, czego przejawem będzie rozwinięcie się języka zespołu, często niezrozumiałego dla osób spoza tego uprzywilejowanego kręgu. Wymaga to jednak czasu oraz występowania w tymże czasie tak zwanego komentarza towarzyszącego oraz zwyczajnych rozmów związanych z pojawiającymi się problemami i sposobami ich rozwiązania. Innym zagadnieniem, na które warto zwrócić szczególną uwagę, jest naturalność języka.

Społeczna funkcjonalność komunikacji. Dotychczasowe przemyślenia związane z pragmatyką komunikacji wynikały przede wszystkim z informacyjnej użyteczności języka. Poza tymi aspektami egzystują jednak pewne społeczne uwarunkowania komunikacji osób niewidzących, odbywającej się przecież w świecie widzących oraz będącej też komunikacją z widzącymi. Przysłuchując się rozmowom osób niewidzących, daje się zauważyć wysoką sprawność w posługiwaniu się słowami znamionującymi bogactwo wrażeń o treści wzrokowej ${ }^{5}$. Zjawisko to można wytłumaczyć tym, że niewidzący posługują się słownikiem ludzi widzących, używając wyrazów i określeń rzeczywistości i przypisując im często tylko sobie znaną treść oraz pewne uczuciowe jakości natury niewzrokowej (Sękowska 1981).

Grzegorzewska (za Sękowska 1981: 75-76) ową lukę w formie odtwarzania spostrzeżeń określa jako substytuty psychiczne treści poglądowych, które ludziom niewidzącym są niedostępne, a odgrywają ważną rolę w kształtowaniu świata wyobraźni i pojęć. Wyobrażenia te, objawiające się językowo, określane są mianem wyobrażeń zastępczych, czyli surogatowych. Zjawisko to można interpretować jako dążność do zdobycia jak największej ilości danych o świecie. Jednocześnie problem ten jest istotny ze względu na społeczną funkcjonalność języka. Funkcjonalność ta powinna być rozumiana również jako zaniechanie (głównie poprzez widzących rozmówców, nauczycieli) poszukiwania określeń będących synonimami tych stosowanych potocznie i odwołujących się do zdolności wizualnej percepcji świata. Innymi słowy społeczna funkcjonalność komunikacji przejawiać się będzie naturalnością języka oraz wychodzeniem naprzeciw pewnym komunikacyjnym utrudnieniom. Poszukiwanie takich synonimów wynika najczęściej z obaw by nie urazić osoby niewidomej, ale te intencje mogą zostać słusznie zinterpretowane jako brak profesjonalizmu i nieumiejętność odnalezienia się w sytuacji pracy z osobą niewidzącą. O ile bowiem niewidzący uczeń nie może zobaczyć w sensie dosłownym demonstracji ćwiczenia, o tyle może na podstawie sobie dostępnych źródeł informacji (np. dotykowych) zbudować portret wyobrażeniowy przyjętej pozycji czy wykonywanego ruchu. Podobnie

${ }^{5}$ Kiedy jeden $\mathrm{z}$ niewidzących uczniów, bez poczucia światła z wysiłkiem pokonywał trudne wspinaczkowo miejsce, w końcu zmęczony podsumował swój stan, bliski - jak opisał go później zawrotom głowy: „ale mi pociemniało w oczach”. 
celowe unikanie sformułowań typu to do zobaczenia, popatrz na to będą przejawem kłopotliwej nieświadomości (w niektórych sytuacjach odbieranej nawet jako rodzaj dyskryminacji), że niewidzący również postrzega. Inne utrudnienia w szerzej pojętych działaniach komunikacyjnych stawiają osoby niewidome w sytuacji, gdzie drobne, aczkolwiek znaczące, problemy utrudniają im wypełnienie swojej roli rozmówcy. Będzie to przykładowo rozpoznanie partnera rozmowy, pozdrowienia (np. podanie dłoni), rozpoznanie niewerbalnych fenomenów komunikacji (gestykulacja, mimika). Wychodzenie naprzeciw takim komunikacyjnym utrudnieniom jest elementem socjalizacji i integracji niewidzących uczniów w świecie ludzi widzących. Pełne uczestnictwo w zdarzeniach świata ludzi widzących odzwierciedlać będzie między innymi naturalność opisanych wyżej konstrukcji i zachowań komunikacyjnych. Nie można tu również pominąć - zdawałoby się drobnej, lecz jakże istotnej - roli humoru, żartu i dowcipu, które potrafią zdziałać więcej na rzecz naturalnej i nieobarczonej kłopotliwą ciszą komunikacji niż każde naukowe opracowanie tego tematu' ${ }^{6}$.

Informowanie zwrotne wykorzystuje różnego rodzaju informacje o wszelkich aspektach ruchu, mogące mieć wpływ na dalszy sposób jego wykonywania, przy czym najczęściej chodzi o utrzymanie lub poprawienie wykonywania czynności ruchowej do poziomu uznanego za wzorcowy (Sas-Nowosielski 2002b). Innymi słowy jest informacją o skutkach i sposobie wykonania ruchu. Istnieją różne możliwości przekazywania informacji zwrotnej. Można ją przekazywać w sposób zamierzony (np. instrukcje słowne nauczyciela), a często także w sposób niezamierzony (np. intonacja głosu). W każdych okolicznościach procesu uczenia się, zarówno zdobywania wiedzy, jak i uczenia się nowych umiejętności, ludzie potrzebują, by ich utwierdzać w tym, co robią dobrze, i zachęcać do zmian w obszarach mniejszej skuteczności. Jedną z fundamentalnych zasad edukacji fizycznej jest przekazywanie przez nauczycieli osobom wykonującym czynności ruchowe specyficznej i korygującej, a częstokroć nawet tylko ogólnej, informacji zwrotnej (Rokosz, Laptad 1997). Najistotniejsze z punktu widzenia nauczania czynności ruchowych jest stosowanie sprzężenia zwrotnego w celu dostarczenia informacji dotyczących poprawiania pojawiających się błędów. Należy też podkreślić, że w przypadku osób niewidzących niewystarczające źródła wewnętrzne informacji zwrotnej, a szczególnie brak informacji wizualnych (np. wizualna kontrola pozycji umożliwiająca wyobrażenie i określająca jej zgodność z przedstawionym/zalecanym wzorcem) stwarza zwiększone zapotrzebowanie na informacje zewnętrzne, nawet tak błahe jak ogólna informacja dobrze!

${ }^{6}$ Warto przywołać zabawny przykład rozładowujący niepotrzebne napięcie za pomocą żartu, $\mathrm{w}$ tym wypadku przez ucznia. Nauczyciel, nie mogąc znaleźć porzuconego gdzieś przyrządu asekuracyjnego, głośno daje wyrazy zniecierpliwienia tym faktem. Niewidomy uczeń komentuje to: „jeśli wejdziesz między wrony...”. 


\section{Uwagi końcowe}

Podsumowując, należy podkreślić, że podjęty temat, będąc niezmiernie istotny dla praktyki nauczycielskiej, zdecydowanie wykracza poza przykłady przytoczone w tekście. Należy zwrócić szczególną uwagę na to, że instrukcja słowna w pracy z osobami niewidzącymi musi spełniać pewne wymogi związane ze specyfiką tej pracy. Instrukcja słowna musi zatem:

- do czegoś się odnosić, na coś się powoływać; relewantne informacje znajdują się w czymś, ale nie w samych słowach;

- być zsubiektywizowana, czyli musi liczyć się z indywidualnymi możliwościami konstruowania znaczeń przez adresata;

- musi zawierać sens, znaczenie lub je konstytuować;

- musi określać cel konkretnego działania, do którego się odnosi;

- musi budować antycypację, określać oczekiwane rezultaty działań;

- nie może zatracać swojego sensu w semantycznie pustym, drobiazgowym przywiązywaniu wagi do detali, co przejawia się werbalizacją.

Powyższe wnioski odnoszące się głównie do pragmatycznej sfery komunikacji warto uzupełnić, sygnalizując możliwe i bardzo pożądane konsekwencje uniwersalne. Komunikacja bardzo ściśle wiąże się z postrzeganiem, jest jednym z przejawów kontaktu ze światem. Można uznać, że proces postrzegania będzie tym skuteczniejszy, im więcej doświadczeń zostanie nagromadzonych w odniesieniu do różnych sytuacji, język zaś nie stanowi w tych procesach wyłącznie medium odzwierciedlenia rzeczywistości. Język porządkuje wyobrażenia i jest środkiem przekazu towarzyszącym procesom poznawczo-analitycznym oraz procesom planowania, pozwala na budowanie trwałej motywacji i zapewnienie bezpieczeństwa (rozumianego również jako potrzeba).

Postrzeganie jest zdolnością indywiduum, a nie zjawiskiem na scenie jego świadomości. Jest bliskim kontaktem utrzymywanym ze światem, raczej zbieraniem doświadczeń aniżeli ich posiadaniem. Postrzeganie oznacza uwagę zwróconą na coś, a nie uświadomienie sobie czegoś (Gibson 1982: 271).

Wydaje się, że społeczne funkcjonowanie człowieka technologicznego jest obciążone licznymi „niesprawnościami”, które nie są tak dobrze widoczne jak brak wzroku. W świecie niewiarygodnej wręcz szybkości przepływu informacji relacje oparte na nowej kulturze komunikacji noszą znamiona powierzchowności i ulotności. Cywilizacja wymaga „naprawy” (Szmyd 2004), człowiek zaś „prostomyślności” (Bańka 2011). Być może w wymiarze jednostkowym uważność poświęcona komunikacji, wspomagająca zasięg potencjalnych szans oraz relacje budowane na odpowiedzialności (co zasadza się przecież na wspinaczkowym partnerstwie - symbolicznym „wiązaniu się liną na dobre i na złe") stają się szansą na dostrzeżenie tego, co niezwykle ważne, choć pozostające poza zasięgiem wzroku. W kontaktach między ludźmi najwyższą wartość jako nośnik informacji ma przecież ciągle jeszcze słowo. 


\section{Bibliografia}

Bańka J. (2011). Etyka prostomyślności a pokrzywione drzewo człowieka. „Res Humana”, 5: 14-19.

Caprano R., Sinz H. (2008). Hoch hinaus an der Kletterwand, Therapeutisches Klettern - ein Fallbericht. „Physiopraxis”, 3: 36-39.

Czabański B. (1998). Wybrane zagadnienia uczenia się i nauczania techniki sportowej. Wydawnictwo AWF, Wrocław: 31-32, 104-105.

Esser I., Bartik F. (2002). Klettern in der Ergotherapeutischen Praxis. „Ergotherapie und Rehabilitation", 3: 17-25.

Friedrich G. (1985). Die Sprache und ihre Funktion im Sport mit Sehgeschädigten, wykład wygłoszony podczas seminarium Bewegung, Spiel und Sport mit Sehgeschädigten, Marburg (materiały udostępnione przez autora).

Friedrich G. (1989). Sprachspezifische Aspekte des Sportunterrichts mit sehgeschädigten Schülern. „Muttersprache”, 3: 265-268.

Friedrich G., Hildenbrandt E. (1990). Sprache im Rahmen von Bewegungslehrprozessen unter Berücksichtigung fehlender visueller Kontrolle bei Sehgeschädigten, w: B. Spillner (red.), Sprache und Politik. Kongressbericht zur 15 Jahrestagung der Gesellschaft für Angewandte Linguistik. GAL, Frankfurt-Bern: 259.

Geisteiner E. (2009).Über sich selbst hinauswachsen. Therapie und Abenteuer in den Bergen. Ergopraxis, 9: 35-37.

Gibson J.J. (1982). Wahrnehmung und Umwelt, München-Wien-Baltimore, w: G. Friedrich (red.), Sprachspezifische Aspekte des Sportunterrichts mit sehgeschädigten Schülern. „Muttersprache", 3: 271.

Grabowski H. (1992). Rola psychologii w kształceniu nauczycieli wychowania fizycznego, w: J. Zdebski (red.), Psychologia wobec wychowania fizycznego. „Zeszyty Naukowe AWF Kraków", 67: 7-12.

Haag D. (2009). Polytrauma - physiotherapeutisches Management, von der Intensivstation an die Kletterwand. „Zeitschrift für Physiotherapeuten”, 7: 647-650.

Hofferer M., Royer S. (2001). Klettern mit Kindern mit Problemverhalten in der kommunikationspädagogisch-psychotherapeutischen Behandlung. „Schweizerische Zeitschrift für Heilpädagogik", 3: 7-14.

Krick M. (2001). Klettern als Therapie - Gruppenarbeit mit SI-Kindern. „Ergotherapie und Rehabilitation", 7: 17-23.

Lillotte R. (2003). Psychomotorische Entwicklungsförderung am Beispiel eines Kletterprojekts in einem offenen, integrativen Kinder- und Jugendhaus. „Praxis der Psychomotorik”, 3: 177-186.

Rokosz F., Laptad R. (1997). On the Learning and Teaching of Physical Skills. „JOPERD”, 68 (2): 5.

Sas-Nowosielski K. (2002a). Informacja werbalna w nauczaniu czynności ruchowych, „Kultura Fizyczna", 9-10: 7.

Sas-Nowosielski K. (2002b). Sprawne komunikowanie się z zawodnikami - ważna umiejętność trenera. „Sport Wyczynowy”, 3-4/447-448: 49.

Sękowska Z. (1981). Tyflopedagogika. PWN, Warszawa: 75-76. 
Swędzioł W. (2013a). Dekalog nauczyciela wspinaczki, w: P. Drożdż (red.), 100 porad Gór, t. 2, Wydawnictwo Góry Books, Kraków: 256.

Swędzioł W. (2013b). Wprowadzenie do wspinaczki i turystyki wspinaczkowej osób niewidzących. „Folia Turistica”, AWF Kraków, 29: 65.

Szmyd J. (2004). Józef Bańka o „naprawie” cywilizacji. „Res Humana”, 13-16.

Winiarski R. (1992). Psychologiczne podstawy wychowania do kultury fizycznej. Wybrane zagadnienia, w: J. Zdebski (red.), Psychologia wobec wychowania fizycznego. „Zeszyty Naukowe AWF Kraków”, 67: 51. 